\title{
Cooperative Federalism and Policy Implementation: The Children's Health Insurance Program for the Latino Population
}

\author{
Mark Stevens \\ Lead Management and Program Analyst, \\ National Institutes of Health(NIH) \\ Yongjin Sa \\ (Corresponding Author) \\ Assistant Professor, Department of Public Administration, \\ Keimyung University
}

\begin{abstract}
With ongoing debates in Washington about the proper role of government in the provision of health care, especially during tight fiscal times, this paper examines current federal-state relations on the implementation of the Children's Health Insurance Program. The paper focuses specifically on the cooperative nature of the relationship between federal and state governments with regards to insuring lowincome, uninsured Latino children. While the cooperative nature will continue, program implementation will be difficult to maintain in the future because of the uncertainties of resources provided to the states, commitment of political leaders to the program's goals, the complexity of joint action involved, and the diversity of the Latino population. The theoretical framework, program context, and findings of this research are specifically discussed.
\end{abstract}

Key Words: Federalism, Cooperative Federalism, Policy Implementation, Children's Health Insurance Program

\section{INTRODUCTION}

Among many public health issues facing the U.S. population is the enduring need to care for uninsured children in low-income families. According to the Kaiser Family Foundation (2011), 8 million children remain uninsured, including 5 million who are eligible for Medicaid and the Children's Health Insurance Program (CHIP) but not enrolled (Key Facts, February 2011). As the U.S. economy recovers from the devastating effects of the economic downturn also known as the "Great Recession," low-income parents have relied more on public health insurance coverage as a means to cover their dependent children. As many low-income parents have lost their jobs along with private health coverage, CHIP has been effective in providing access to children who would otherwise go without such care.

In spite of federal and state success in expanding health coverage to uninsured children, more action is needed to reach those who have no health coverage, particularly those belonging to the Latino community. Many of the unim nsured belong to families where parents are unaware of CHIP, which makes public awareness and outreach important in reaching these groups. Statistics compiled by the U.S. Census Bureau clearly show a growing Latino population throughout the U.S. making it the largest and fastest growing minority group. One could argue that this growing community presents a challenge for intergovernmental actors to be more responsive to their public health needs. In this context, this paper explores the cooperative 
federalism framework to support the success of CHIP and the issue that impede program effectiveness of CHIP based on the policy implementation framework.

\section{GROWING LATINO POPULATION}

Health insurance coverage is important for all American children, especially those of Latino families. According to the U.S. Census projections, Latinos are the largest and fastest growing minority group in the U.S. making up $15 \%$ of the population (see figure 1).

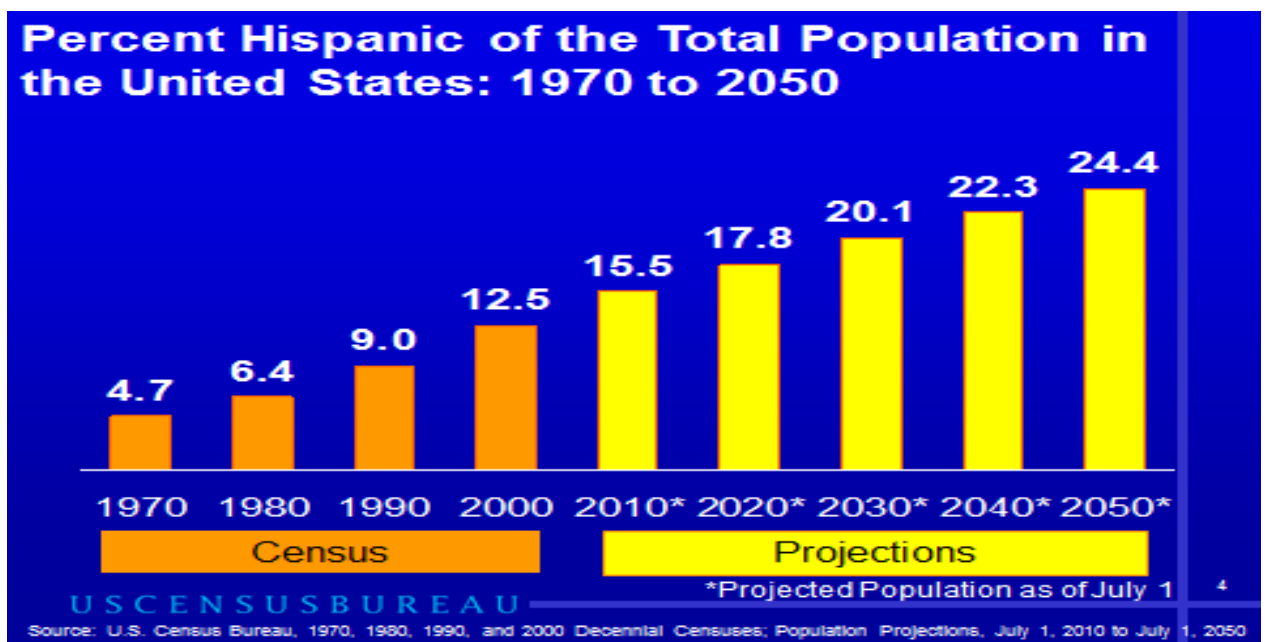

Figure 1: U.S. Census Bureau, Percent Hispanic of the Total Population in the United States: 1970 to 2050.

This problem is even more pronounced among Latino children ages 0-19. According to the U.S. Census report, there is a disproportionate lack of health insurance as Hispanics were less likely to be covered by health insurance than non-Hispanic Whites (U.S. Census Bureau, 2001). Research shows that the majority of uninsured children (65\%) live in families with at least one-full-time worker and these families are not offered coverage by an employer or cannot afford the premiums (Key Facts, 2011). Although the rate of uninsured children varies by state, the rate is $15 \%$ in four states in the U.S. (FL, NM, NV, TX) and all uninsured children account for $36 \%$ in five states (CA, FL, GA, NY, TX), four of which are the four largest states in the nation (Key Facts, February 2011). It is imperative to enroll eligible low-income children to assure coverage for all of America's children.

\section{CHILDREN'S HEALTH INSURANCE PROGRAM}

Policymakers and implementors in present-day intergovernmental relations have continued to grapple with the important public policy issues. According to Conlan and Posner (2008), the dominant issues in intergovernmental relations will continue to range from taxation, health care, and federal-state support for entitlement programs, including Medicare services to the elderly and Medicaid services for low-income individuals and the poor. This is most notable with the public provision of health insurance through the Children's Health Insurance Program (CHIP). Passage of CHIP was a bi-partisan effort in the wake of President Clinton's defeat of health care reform efforts during 1994.

Dubay and Kenney (2009) note that passage of CHIP was an unprecedented effort aimed at reaching and enrolling uninsured children in public coverage (Dubay and Kenney, 2009, 2042). Recognizing the importance of addressing this issue, Congress created the Children's Health Insurance Program (CHIP) (Public Law 105-33). Passed as part of the Balanced Budget Act of 1997, the program sought to complement Medicaid coverage to low-income uninsured children who were not eligible for Medicaid. The federal government matches state spending for both Medicaid and CHIP and the rate at which the government matches CHIP spending is 
higher relative to Medicaid (Key Facts, February 2011). CHIP matching funds to support states' efforts to provide health coverage through their State Children's Health Insurance Programs (SCHIP) or Medicaid programs for children ages 0-19 (Key Facts, February 2011). Broaddus (2011) notes that aggregate federal funding for state CHIP programs was set at levels that were more than adequate to meet states' financing needs during CHIP's first ten years (Broaddus, 2011, 2). CHIP is administered by state governments but is jointly funded by the federal government and states.

Congress has enacted several key laws that provide additional resources to CHIP. Among the laws are: The American Recovery and Reinvestment Act of 2009; and the Children's Health Insurance Program Reauthorization Act (CHIPRA) of 2009. According to the Centers for Medicaid and Medicare Services (Department of Health and Human Services, Centers for Medicare and Medicaid Services, 2010), the 2009 American Recovery and Reinvestment Act (ARRA), also known as the Stimulus, provides financial incentives to states health providers who "adopt, implement, upgrade, or meaningfully use certified Electronic Health Records (CMS 2010).

According to the Department of Health and Human Services (2010), the Children's Health Insurance Program Reauthorization Act (CHIPRA) of 2009 provides for performance bonuses to states who have demonstrated that they can reduce the administrative burden of enrolling eligible children in CHIP and SCHIP programs; automatic eligibility of children whose mothers currently enjoy Medicaid; $\$ 10$ million for a national outreach campaign; $\$ 10$ million in grants to Indian Tribes, Indian Health Services providers, and other tribal health care providers, and $\$ 80$ million in grants to promote enrollment and retention in Medicaid and CHIP. Furthermore, the Department of Health and Human Services notes that the 2010 Patient Protection and Affordable Care Act provides substantial new funding for developing a Medicaid adult quality measurement program to complement CHIPRA children's quality measurement program (CMS 2010).

While CHIP has enjoyed bipartisan support throughout the years of its existence it has faced some resistance from politicians who view it as a step towards giving the federal government more power over health care. Democratic and Republican lawmakers support the ideals of CHIP and have witnessed the program's effectiveness in lower the percentage of uninsured children in their respective states and congressional districts. Federal policymakers view this problem as easily defined to a select group of children whose parents are unaware of the resources or to states that have complicated procedures to determine eligibility. However, there are program detractors who argue the bill is costly for the government and pose a "crowding out" risk to the private health insurance carriers. For example, President Bush vetoed a bill in 2007 that would have reauthorized the CHIP based on his view that the bill would "federalize health care, and that is would steer the program away from its core purpose of providing insurance for poor children and toward covering children from middle-class families (Stout, New York Times, 2007)." After much negotiation between the parties, the President ultimately signed the bill.

\section{COOPERATIVE FEDERALISM FRAMEWORK}

American federalism has involved cooperation and conflict between the federal and state levels of government for over 200 years. Scholars attribute this dynamic relationship in federal and state relations dating back to the time period when state constitutions predated the federal constitution. Decentralized government dominated the governance of state domestic policy affairs and continued to do so under the Articles of Confederation. Born out of dissatisfaction with the Articles, the creation of the national government sought to address 
unity, economics and commerce, and a design for the division of power and building of democratic institutions. Throughout American history, a "creative tension" has characterized federal-state relations as the states have assumed more responsibilities in administering and financing federal programs. With this responsibility, states have been asked to modernize their governmental structures and processes to build their capacity to deliver public services.

One could argue that the debate over the proper role of the federal government in relation to the States is a classical debate that led to the origins of American public administration. On the one hand, the federalists, such as Alexander Hamilton and to a large degree, James Madison, were individuals who endorsed to the ideals of a strong, national government, viewed the Articles as incapable of addressing the collective needs of the nation. On the other hand, the anti-federalists, viewed the idea of having such a national body as a direct threat to state sovereignty, leading to more federal intervention in state affairs. The tension between federalists and anti-federalists continues to this day. The federal government continues to rely on state governments to implement public policy. This is certainly true in the public health arena. In particular, the issue of children's health insurance includes federal and state cooperation in an effort to cover more of America's low-income children.

The interrelationship of financing and shared power in federal and state relations has forced policymakers to consider the implications to policy and program implementation. In support of congressional action establishing the 1953 Commission on Intergovernmental Relations, President Eisenhower, in a message to Congress, observed:

"In the state of the Union message I expressed my deep concern for the well-being of all of our citizens and the attainment of equality of opportunity for all. I further stated that our social rights are a most important part of our heritage and must be guarded and defended with all of our strength. I firmly believe that the primary way of accomplishing this is to recommend the creation of a commission to study the means of achieving a sounder relationship between Federal, State, and local governments" (Butler,1955,v).

Formally known as the Commission on Intergovernmental Relations, but also referred to as the Kestnbaum Commission in honor of committee Chairman, Meyer Kestnbaum, was created to find solutions to intergovernmental issues and challenges between the federal and state governments. With a temporal frame ranging from 1953-1955, the Commission released its report in 1955 drawing attention to the "the proper role of the federal government in relation to the States and their political subdivisions (Butler, 1955)." The Commission thought it necessary to examine whether or not intergovernmental functions and fiscal relations (extending federal grants-in-aid) needed to be adjusted for the carrying out of public policy.

CHIP is a classic example of the cooperative federalism framework. According to Pear (1997), federalism issues were a key part of the debate over whether to give money as a block grant or as an expansion of Medicaid, which retains a strong federal presence. According to Scheiber (1966), the model of cooperative federalism portrays the present-day federal system as one in which most of the important functions of government is shared (Scheiber, 1966, 65). Cooperative federalism demands "greater emphasis on the skills of indirect governance: understanding and mobilizing diffuse networks, placing a premium on bargaining skills and employing incentives, nurturing professional relationships" (Conlan, 2008, 38).

The interplay between the federal and state governments over the implementation of CHIP provides a good opportunity to explore this issue through the cooperative framework. The literature suggests that federalism involves "creative tension" between federal and state 
governments that often lead to conflict or cooperation. As Wright (1988) notes, cooperative federalism is generally considered to have characterized the intergovernmental system from the 1930s to the 1960s (Conlan and Posner, 2008, 33). It was during this period that the federal government shifted program implementation and management to the states giving rise to an unprecedented mix of sharing functions and responsibilities (Conlan and Posner, 33). Further research into intergovernmental relations between the federal and state levels government will be needed to find ways to streamline the administrative process between the both layers.

The literature on intergovernmental relations suggests scholars and practitioners use various frameworks to explain the theories, concepts, and behaviors of federal and state relations. Cooperative federalism is one of the more dominant frameworks in intergovernmental relations. According to Conlan (2006), throughout the 1950s and into the 1960s, the paradigm of cooperative federalism blossomed (Conlan, 2006, 666). Cooperative federalism is credited primarily with ushering in an era of expanded federal aid to states through the federal grants system (grants-in-aid). Conlan (2006) maintains the U.S. saw the continued expansion of public health, agriculture, and urban renewal grants throughout the 1960s (666). Zimmerman (2001) notes that Elazar in 1962 conceived cooperative federalism-implying a "division of functions between governments as well as a division of governmental structures (Zimmerman, 2001, 18)." Elazar (1967) notes that the theory of cooperative federalism assumes a division of structures and a system of sharing that ranges from formal federal-state agreements covering specific programs to informal contacts on a regular basis for the sharing of information and experience.

Access to health insurance for America's low-income children is an important issue facing the U.S. The financing and implementation of health insurance coverage for low-income children between the ages of 0-19 has become an interesting intergovernmental issue facing federal and state public officials who administer public health programs (Kaiser Commission, 2011). Created in 1997, the Children's Health Insurance Program (CHIP) serves as a tremendous public sector effort to assist low-income, uninsured children who would otherwise be uninsured because of the lack of access to affordable health insurance. According to U.S. Census data, more than 7 million children are uninsured (U.S. Department of Health and Human Services, 2010, 4.). It is undeniable that states are increasingly asked to carry out federal programs, such as CHIP, to ensure eligible children in low-income families receive health insurance. Given the dire economic conditions in the U.S. of high unemployment over $8 \%$ and the depletion of state coffers with many facing severe deficits, one might expect states to face a greater burden of providing CHIP coverage.

The provision of publically-funded health care is a controversial issue that can be traced back to America's founding fathers and their views on the proper role of government. There is a long-standing debate between the ever-expanding role of the federal government in state domestic policy matters. The origins of this debate can be traced back to the federalists and anti-federalists during the country's earliest founding. Prior to the development of the federal design, the nation was governed by the Articles of Confederation which afforded the states great latitude for governing their domestic policy issues. As advocates of a strong national government, the federalists wanted to move away from the Articles in search of a national body that would attend to the needs of the country collectively: unity, economics and commerce, and a design for the division of power and building of democratic institutions. A federal government, from the viewpoint of the anti-federalists, amounted to an affront to their ideals of local power and control through small government and liberty from government bureaucracies. 


\section{POLICY IMPLEMENTATION: MAZMANIAN AND SABATIER(1981) FRAMEWORK}

The success of the CHIP depends solely on political support and on the implementation process. Edwards (1980) defines policy implementation as the "the stage of policymaking between the establishment of a policy - such as the passage of a legislative act, the issuing of an executive order, the handling down of a judicial decision, or the promulgation of a regulatory rule and the consequences of the policy for the people whom it effects" (Edwards, 1980, 1). Policymakers and implementors can expect CHIP implementation to be difficult due to a number of key factors. Implementation will be influenced by the greater the extent of behavioral change called for among the targeted population of low-income families. Implementation barriers also include less clear, consistent communication among the actors; less adequate the resources provided to implementors; the less committed leaders are to the policy goals; and the greater the diversity of the Latino population of low-income families.

In order to address the issue of lack of health insurance among children, one could argue the most useful and appropriate conceptual framework on the CHIP implementation process is provided by Mazmanian and Sabatier (1981). The framework put forth by Mazmanian and Sabatier offers a valid theory connecting behavior change of parents to enroll uninsured children thereby solving the issue. Since we know that a child's risk of being uninsured depends on family structure and where they live, public officials need to consider the dependent variable or the stages of the implementation process.

\section{Policy Implementation Framework (PIF)}

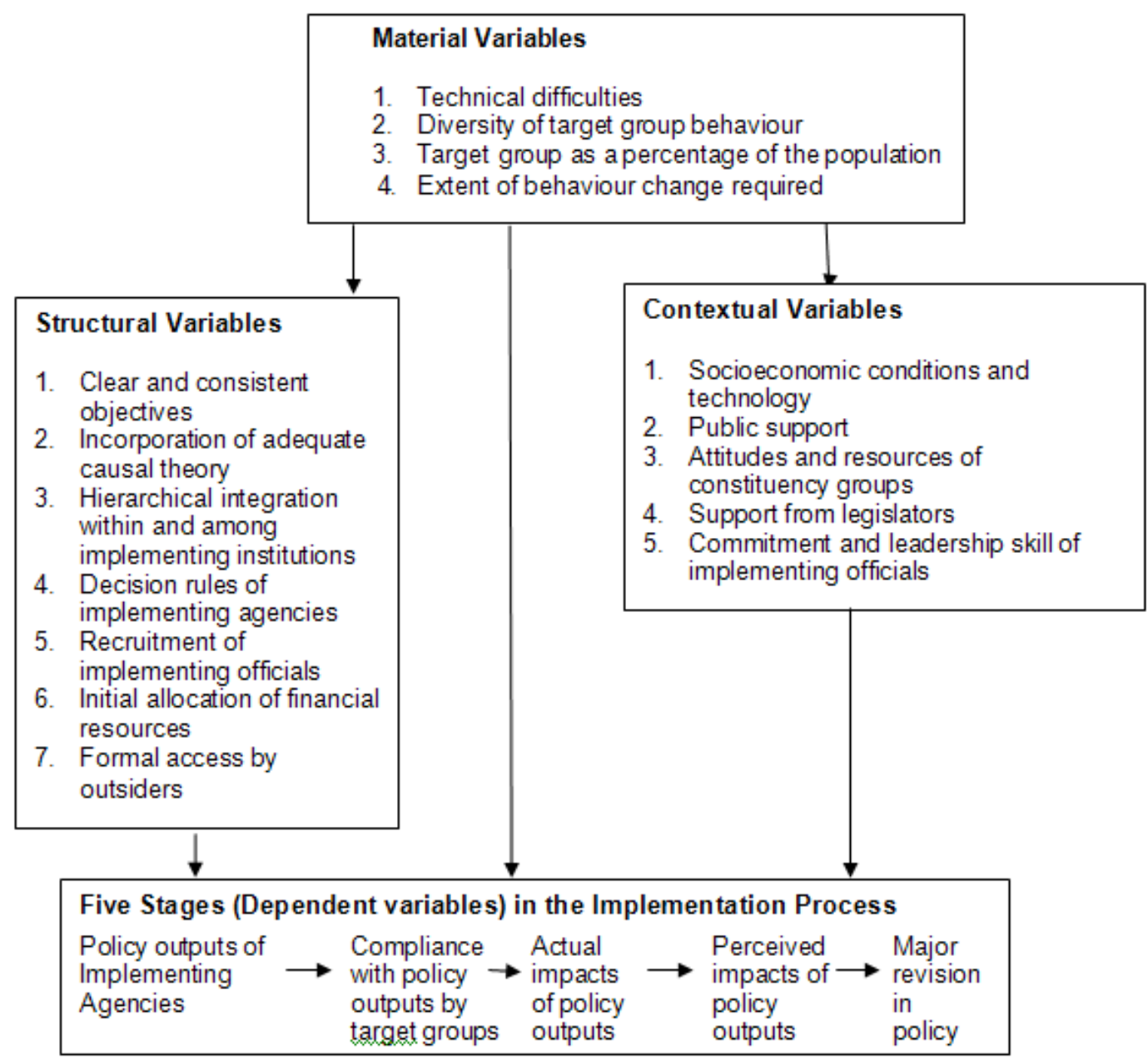

Figure 2: Mazmanian \& Sabatier (1981) Policy Implementation Framework 


\section{Statutory Independent Variables}

Priority to low-income Latino families with uninsured children must be communicated by CHIP's objectives. Any new directive without this sense of urgency or specificity will likely mean a delay in targeting the Latino population during program implementation. CHIP's program performance is directly tied to adequate causal theory. It is necessary that CHIP implementation to increase Latino involvement have causal theory clearly articulates the linkage between governmental intervention and the program's objectives. Also, the interaction between HHS officials and state government officials provide for critical sufficient jurisdiction and over actually obtaining the objectives. The intergovernmental nature of CHIP's implementation requires coordinated efforts between the federal and state governments.

While CHIP is a federal program, the states are the "driving force" behind program implementation. Hierarchical integration should be closely tied because loose integration presents the risk of having varied implementation among the states. CHIP legislation should include inducement and rewards to overcome potential veto clearance points throughout implementation. Compliance among all actors should be the goal. Although CHIP has received over $\$ 40$ billion in federal funding since its creation, additional federal and state funds will be needed to target the Latino population. The new program scope may require additional hire of bilingual staff and support. Clear, concise decision rules should be promulgated by HHS and partnering state agencies. The CHIP statute should eliminate confusing policies and complex enrollment and renewal policies for Latino families.

The solvability of the problem of covering uninsured, low-income children Latino children depends on the manageability of the issue. Mazmanian and Sabatier (1989), note that the smaller and more definable the target group the more likely the mobilization of political support in favor of the program and thus more probable the achievement of statutory objectives (24). Changes in CHIP implementation for state governments will require new and improve technologies to target the Latino population. According to the National Alliance for Hispanic Health (NAHH), technological capabilities will be need for collecting data by race and ethnicity (203).

\section{Non-Statutory Independent Variables}

The economic recession facing the U.S. makes the issue of insuring eligible Latino children politically salient for a number of reasons. Congressional leaders and the public most likely will view the program as critical given the loss of jobs and health insurance benefits that are attached to such employment. The demand to insure children is even greater during these difficult economic times. Not to mention, the growing Latino population has made it politically palatable to the Democratic and Republic parties to seek support from the Latino community its policy implications. It should be noted that there is variation in public support for public health programs. Public support most likely will depend on the economic and political considerations at the time of implementation. Major Latino constituency group could play a major role in supporting the government's efforts to enroll more Latino children and could act as an advocate.

\section{Stages: Dependent Variables}

The policy outputs should be consistent the program's intent to enroll more Latino children in CHIP. CHIP implementation should include policies and procedures that accommodate lowincome, Latino parents. As recommended by the NAHH, the development of "streamlined and bilingual program applications must be produced to assist Latino parents (NAHH, 2003, 41.). The dissemination of Spanish informational materials will better assist Latino parents in making decisions. CHIP will actually achieve its desired impacts if: policy outputs are 
consistent with statute objectives; target groups comply with outputs; no conflicting statutes; and statute incorporates causal theory linking behavioral change in target groups to the achievement of mandated goals (Mazmanian, 1989, 37).

\section{DISCUSSION AND CONCLUSION}

The CHIP is the nation's premier federal tool that provides states with the financing needed to insure eligible Latino children. Given the gridlock of the political process and the precarious economic condition of the U.S. economy, continued support of CHIP is politically salient and likely to draw bi-partisan support for the foreseeable future. Congressional leaders and the public most likely will view the program as critical given the loss of jobs and health insurance benefits that are attached to such employment.

Federal-state intergovernmental relations over CHIP face a number of implementation barriers that must be considered by scholars and practitioners. Although the solvability of the problem of covering uninsured, low-income Latino children is manageable, there are real uncertainties over the resources provided to the states by the federal government. Mazmanian and Sabatier (1989), note that the smaller and more definable the target group, the more likely the mobilization of political support in favor of the program and thus more probable the achievement of statutory objectives $(1989,1989,24)$. Targeting the Latino population presents an opportunity to achieve real results in enrolling more eligible children.

Funding levels will depend on the commitment of political leaders to the program's original goals and intent. Conlan (2006) argues that the cooperative framework has largely unraveled due to a change in the federal system from intergovernmental management to performance management (666). The complexity of joint action involved among federal and state implementors could be amplified given the rich diversity of the Latino population (i.e. Mexican Americans, Puerto Ricans, and Cuban Americans, just to name a few).

Intergovernmental relations will continue to be influenced by the cooperative framework in addressing public administration issues. Federal and state governments will continue to debate over policy matters and which level of government has the appropriate purview over them. The states will contend they have the best policy prescriptions and corrective actions for many public policy issues, while federal officials will argue they are better suited to handle such matters. While it is uncertain how this relationship will develop in the future, it is clear the war of ideas will continue as both sides work to build the perfect union.

A review of the literature on implementation would suggest that future implementation of CHIP will be more difficult to achieve. Since access to health coverage for the number of uninsured Latino children is the focus of this paper, the measure of CHIP success is measured in terms of the number of children enrolled. Action needs to be taken to incorporate cultural competency into the policy implementation of CHIP. In particular, the focus of the program should be on the growing number of low-income, uninsured Latino children. National statistics clearly show that the Latino population is burgeoning in many parts of the country, and with this dramatic population shift, it is incumbent on public administration to be culturally competent to the needs of the community. While CHIP has done a remarkable job of enrolling children across racial and ethnic backgrounds since 1997, more work needs to be done to ensure that all of America's children have access and affordability to health care insurance. This truth holds implications for the health of the nation and the productivity of its workforce. 


\section{References}

Broaddus, Matt. (2011). CHIP's Success Not an Argument for Block-Granting Medicaid: Congress took Steps to Ensure Adequate Federal CHIP Funding for States, but Funding Would be Inadequate under Medicaid Block Grant. Center on Budget and Policy Priorities. June 28. Accessed on February 17, 2017 at: http://www.cbpp.org/files/629-11health.pdf.

Butler, John M. (1955). The Commission on Intergovernmental Relations: A Report to the President for Transmittal to the Congress: Washington, DC.

Congress of the United States, Congressional Budget Office. (2007). A CBO Paper: The State Children's Health Insurance Program. May. Accessed on February 17, 2017 at:

http://www.cbo.gov/sites/default/files/cbofiles/ftpdocs/80xx/doc8092/05-10-schip.pdf.

Conlan, Timothy J. (2006). From Cooperative to Opportunistic Federalism: Reflections on the Half-Century Anniversary of the Commission on Intergovernmental Relations. Public Administration Review. Sept/Oct. 66 (5): 663-676.

Conlan, Timothy J., and Paul L. Posner. (2008). Intergovernmental Management for the 21st Century, The Brookings Institution.

Dubay, Lisa and Genevieve Kenney. (2009). The Impact of CHIP on Children's Insurance Coverage: An Analysis Using the National Survey of America's Families." Health Services Research. December 44 (6)

Edwards III, George C. (1980). Implementing Public Policy. Washington: Congressional Quarterly Press.

Elazar, Daniel J. (1967). The American Partnership: Intergovernmental Cooperation in the Nineteenth Century United States. University of Chicago Press.

Ho, Vivian and Marah Short. (2009). Baker Institute Policy Report 40: The Economic Impact of Uninsured Children on America. http://www.bakerinstitute.org/publications/HPF-pub-HoShortUninsuredChildren-060309.pdf. Accessed on May 4, 2017.

Kaiser Commission on Medicaid and the Uninsured. (2011). "Health Coverage of Children: The Role of Medicaid and CHIP." February. http://www.kff.org/uninsured/upload/7698-05.pdf. Accessed on May 6. 2017.

Mazmanian, Daniel A. and Paul A. Sabatier. (1989). Implementation and Public Policy. Lexington Books.

Mazmanian, Daniel A. and Paul A. Sabatier. (1981). Effective Policy Implementation. University Press of America.

National Alliance for Hispanic Health. (2003). Improving SCHIP Access for Hispanic Children: Report and Recommendations from the Field. http://www.ncfh.org/pdfs/5479.pdf. Accessed on May 4, 2017.

Pear, Robert. (1997). 24 Billion Would Be Set Aside for Medical Care for Children. New York Times, July 31, p. A13.

Rice, Mitchell F. (2010). Diversity in Public Administration: Theories, Issues, and Perspectives, $2^{\text {nd }}$ ed. Armonk, NY: M.E. Sharpe.

Smith, Vernon, David Rousseau, Caryn Marks and Robin Rudowitz. (2008). SCHIP Enrollment in June 2007: An Update on Current Enrollment and SCHIP Policy Directions. Kaiser Commission on Medicaid and the Uninsured. Kaiser Foundation. Accessed on April 9, 2017 at: http://www.kff.org/medicaid/upload/7642_02.pdf.

Scheiber, Harry N. (1966). The Condition of American Federalism: An Historian's View, In American Intergovernmental Relations 3rdedition. O'Toole, Laurence J., Jr. CQ Press, 2000.

Stout, David. (2007). "Bush Vetoes Children's Health Bill.” New York Times. Published on October 3. Accessed on February 17, 2017 at: http://www.nytimes.com/2007/10/03/washington/03cnd-veto.html.

U.S. Census Bureau. (2001). Health Insurance Coverage: 2001. Access on May 4, 2017 at: http://www.census.gov/prod/2002pubs/p60-220.pdf.

U.S. Department of Health and Human Services, Centers for Medicare and Medicaid Services. (2010). The Department of Health and Human Services Children's Health Insurance Program Reauthorization Act Annual Report on the Quality of Care for Children in Medicaid and CHIP. September. Accessed on February 17, 2017 at: https://www.cms.gov/MedicaidCHIPQualPrac/Dowloads/secrep.pdf.

U.S. Department of Health and Human Services. (2010). Children's Health Insurance Program Reauthorization Act. 2010. Accessed on February 17, 2017 at:

http://www.insurekidsnow.gov/professionals/reports/chipra/2010_annual.pdf. 
U.S. Government Printing Office. "Balanced Budget Act of 1997, Public Law 105-33." Accessed on April 21, 2017 at: http://www.gpo.gov/fdsys/pkg/PLAW-105publ33/html/PLAW-105publ33.htm.

Zimmerman, Joseph F. (2001). National-State Relations: Cooperative Federalism in the Twentieth Century. Publius: The Journal of Federalism 31 (2): 15-30. 